\title{
MEDIA VIDEO MAKANAN TERHADAP PENGETAHUAN DAN KEPATUHAN DIET SERTA PENGENDALIAN KADAR GLUKOSA DARAH PASIEN DIABETES MELITUS TIPE II
}

\author{
Nonce Nova Legi ${ }^{1}$, Muksin Pasambuna ${ }^{1}$, Rudolf B. Purba ${ }^{1}$, Oktavia Kasiati ${ }^{1}$ \\ Jurusan Gizi Poltekkes Kemenkes Manado \\ email korespondensi : noncenovalegi@gmail.com
}

\begin{abstract}
Changes in lifestyle from year to year increasingly experiencing developments in all fields, including influencing the type of food and consumption patterns and lifestyles. The increasing number of instant foods and drinks with high calorie, low fiber and high fat content increases the risk of developing metabolic and degenerative diseases. Coupled with a lifestyle that lacks physical activity. One of the metabolic and degenerative disorders that arise is diabetes mellitus. This type of research is a quasy experiment pre and post test one group design of 34 respondents. This research will describe the increase in knowledge, diet compliance and control of blood glucose levels in patients with diabetes mellitus at RSUP Prof. Dr. R. D. Kandou Manado. Data analysis for prior and after knowledge using the Wilcoxon test and the level of dietary compliance before and after using the Paired t-test. The results showed that the knowledge of the sample after being given nutritional counseling using food videos increased by $35.3 \%$, from $64.7 \%$ to be better, the level of adherence to the patient's diet after being given nutritional counseling using food videos increased by $2.9 \%$ from $97.1 \%$ and sugar levels blood after being given nutritional counseling using food video media decreased from $261.8 \mathrm{mg} / \mathrm{dL}$ to $195.2 \mathrm{md} / \mathrm{dL}$
\end{abstract}

Keywords: Knowledge, diet compliance level, blood sugar, food video

Perubahan pola hidup dari tahun ke tahun semakin mengalami perkembangan dalam segala bidang, termasuk mempengaruhi jenis makanan dan pola konsumsi serta gaya hidup. Semakin banyaknya makanan dan minuman instan dengan kandungan kalori tinggi, rendah serat dan berlemak tinggi meningkatkan resiko terjadinya penyakit gangguan metabolik dan degeneratif (Mistra, 2004).

Penanganan penyakit diabetes melitus terutama melalui terapi diet yang tepat. Sehingga diperlukan perubahan perilaku konsumsi dan kepatuhan dalam menjalankan diet diabetes melitus untuk meningkatkan kualitas hidup para penderita diabetes dan menghindari terjadinya komplikasi yang mempengaruhi kualitas hidup pasien diabetes. Komplikasi yang terjadi bagi penderita diabetes yang tidak terkontrol gula darahnya diantaranya retinopati (bisa menyebabkan kebutaan), gagal ginjal, neuropathy, aterosklerosis (penyebab stroke), gangren, dan arteri koronaria (coronary artery disease). Akibat dari komplikasi tersebut maka diperlukan penanganan yang tepat dan cepat agar penderita diabetes mellitus dapat terhindar dari komplikasi penyakit (Hardiansyah dan Supariasa, 2016).

Mengingat pentingnya kepatuhan diet bagi para penderita diabetes maka di perlukan media yang tepat untuk mendukung konseling gizi yang diberikan. Media gambar merupakan media yang paling mudah diingat oleh seseorang yang melihatnya dibandingkan media suara (hanya berupa konsultasi). Alat bantu audiovisual seperti slide, film, videotape, model makanan dapat memperjelas informasi. Dengan 
penggunaan media yang menarik dalam bentuk audiovisual dapat meningkatkan konsentrasi dan mencegah kebosanan (Soegondo S,2013).

Pemberian konseling gizi tidak cukup hanya dengan menyampaikan jenis makanan yang harus dikurangi serta olah raga yang cukup, tetapi juga harus mampu mengubah perilaku pasien tentang gaya hidup. Dalam mengubah kebiasaan pola makan pasien tentunya berkaitan dengan mengubah perilaku, pola hidup serta kehidupan sosial pasien. Konseling membutuhkan kemampuan yang perlu pelatihan khusus terutama dalam mengubah pola hidup pasien (Almatsier S, 2010).

Proses konseling gizi merupakan suatu strategi terapi gizi medis dan digunakan untuk pencegahan dan manajemen penyakit kronis seperti diabetes. Penelitian Franz dkk mengatakan bahwa konseling gizi yang tepat dan terstandarisasi terbukti dapat menurunkan kadar gula darah dan menurunkan level HbA1c hingga $2 \%$. Edukasi gizi yang tepat dapat berpengaruh terhadap perubahan pengetahuan pasien Diabetes melitus tipe 2, selain itu juga dapat menurunkan indeks massa tubuh pasien dan metabolik pasien diabetes (Puteri dkk,2015). .

Tujuan penelitian ini bertujuan untuk membuat video makanan yang memuat informasi zat gizi antara lain, ukuran rumah tangga dan beratnya, nilai gizi makro dan kandungan indeks glikemik makanan. Mendokumentasikan hasil pembuatan video makanan dalam bentuk jpg. Mengetahui peningkatan pengetahuan, kepatuhan diet serta kadar glukosa darah pada pasien diabetes melitus di ruang rawat inap RSUP Prof. Dr. R.D. Kandou Manado setelah mendapatkan konseling dengan menggunakan media video makanan.

\section{METODE}

Jenis penelitian ini adalah quasy experiment pre and post test one group design. Penelitian ini mendeskripsikan peningkatan pengetahuan, kepatuhan diet dan terkendalinya kadar glukosa darah pada pasien diabetes mellitus. Variabel penelitian yaitu variabel independen yaitu konseling gizi dengan media video makanan dan variabel dependen yaitu pengetahuan, kepatuhan diet dan glukosa darah sewaktu. Penelitian ini dilaksanakan di ruang rawat inap RSUP Prof. Dr. R.D. Kandou Manado pada bulan Maret - April 2019.

\section{HASIL}

Karakteristik

Sampel

Tabel 1 Distribusi Sampel Penelitian Berdasarkan Jenis Kelamin

\begin{tabular}{|c|c|c|c|c|c|c|c|c|}
\hline $\begin{array}{l}\text { Jenis } \\
\text { Kelamin }\end{array}$ & $\mathrm{n}$ & $\%$ & Pendidikan & $\mathrm{n}$ & $\%$ & Status Gizi & $n$ & $\%$ \\
\hline Laki-laki & 14 & 41 & Dasar & 19 & 56 & $\begin{array}{l}\text { Kurang }(\text { IMT < } \\
18,5)\end{array}$ & 5 & 22 \\
\hline \multirow[t]{2}{*}{ Perempuan } & 20 & 59 & Menengah & 15 & 44 & $\begin{array}{l}\text { Normal ( IMT } \\
18,5-25,0)\end{array}$ & 19 & 59 \\
\hline & & & Tinggi & 0 & 0 & $\begin{array}{l}\text { Lebih ( IMT > } \\
25,0)\end{array}$ & 10 & 29 \\
\hline Total & 34 & 100 & Total & 34 & 100 & Total & 34 & 100 \\
\hline
\end{tabular}

Sebagian besar sampel berjenis kelamin perempuan $(58,8 \%)$. Pendidikan sampel sebagian besar pendidikan Dasar yaitu sebanyak 19 orang (55.9\%). 
Sedangkan status gizi pasien paling banyak mempunyai status gizi normal yaitu sebanyak 19 orang $(55,9 \%)$

\section{a. Tingkat Pengetahuan}

Pengetahuan merupakan salah satu variabel yang diteliti. Pengetahuan meliputi pengetahuan sebelum diberikan konseling dengan menggunakan video makanan (pengetahuan pre) dan pengetahuan sesudah diberikan konseling dengan video makanan. .

Tabel 2 Distribusi Sampel Penelitian Berdasarkan Tingkat Pengetahuan.

\begin{tabular}{lllll}
\hline Tingkat Pengetahuan & \multicolumn{2}{c}{ Kurang } & \multicolumn{2}{c}{ Baik } \\
\hline & $\mathrm{n}$ & $\%$ & $\mathrm{n}$ & $\%$ \\
\hline Sebelum intervensi & 22 & 65 & 0 & 0 \\
Sesudah intervensi & 12 & 35 & 34 & 100 \\
\hline Total & 34 & 100 & 34 & 100 \\
\hline
\end{tabular}

Ada peningkatan pengetahuan sampel sebelum diberikan konseling dan sesudah diberikan konseling gizi dengan menggunakan video makanan. Sebelum diberikan konseling dengan menggunakan video makanan, tingkat pengetahuan sebagian besar $(64.7 \%)$ adalah kurang dan setelah diberikan konseling terjadi peningkatan sebesar $35.3 \%$ dari kurang menjadi baik.

b. Tingkat Kepatuhan Diet

Kepatuhan diet merupakan tindakan pasien dalam menjalankan diet sesuai dengan prinsip diet diabetes melitus. .

Tabel 3 Distribusi Sampel Penelitian Berdasarkan Tingkat Kepatuhan Diet

\begin{tabular}{cccll}
\hline \multicolumn{5}{c}{ Tingkat Kepatuhan Diet } \\
\hline Kategori & \multicolumn{2}{l}{ Sebelum Intervensi } & \multicolumn{2}{l}{ Sesudah Intervensi } \\
\hline & $\mathrm{n}$ & $\%$ & $\mathrm{n}$ & $\%$ \\
\hline Tidak Patuh & 1 & 2.9 & 0 & 0.0 \\
Patuh & 33 & 97.1 & 34 & 100.0 \\
\hline Total & 34 & 100.0 & 34 & 100.0 \\
\hline
\end{tabular}

Pada dasarnya sampel telah memiliki tingkat kepatuhan baik terhadap diet, dimana sebelum diberikan konseling dengan video makanan dari 34 orang, 33 orang diantaranya $(97.1 \%)$ memiliki tingkat kepatuhan diet yang baik dan setelah diberikan konseling menjadi 34 orang $(100 \%)$ memiliki tingkat kepatuhan diet yang baik.

c. Kadar Gula Darah

Pemberian konseling gizi dengan menggunakan video makanan bertujuan untuk meningkatkan pengetahuan sampel sehingga terbentuk kepatuhan dalam menjalankan diet sehingga kadar gula darah dapat dikontrol bahkan dapat diturunkan menjadi normal. 
Tabel 4. Distribusi Sampel Penelitian Berdasarkan Kadar Gula Darah

\begin{tabular}{lllll}
\hline \multicolumn{5}{c}{ Kadar Gula Darah $(\mathrm{mg} / \mathrm{dl})$} \\
\hline & Mean & SD & Minimum & Maximum \\
\hline Gula Darah Pre test & 261.8 & 112.6 & 100 & 570 \\
Gula Darah Post test & 195.2 & 95.4 & 98 & 527 \\
\hline
\end{tabular}

Gula darah setelah diberikan konseling dengan video makanan menunjukan penurunan, yaitu dari 261,8 mg/dl menjadi $195.2 \mathrm{mg} / \mathrm{dl}$, terjadi penurunan sebanyak $66,6 \mathrm{mg} / \mathrm{dl}$.

d. Perbedaan Pengetahuan Sebelum dan Sesudah Diberikan Konseling Video Makanan.

Tabel 5 Hasil Analisis Uji Wilcoxon Pengetahuan Sebelum dan Sesudah Diberikan Konseling Video Makanan.

\begin{tabular}{lccc}
\hline & $\mathrm{n}$ & $\begin{array}{c}\text { Median } \\
\text { (minimum-maksimum) }\end{array}$ & $p$ \\
\hline $\begin{array}{l}\text { Pengetahun } \\
\text { sebelum }\end{array}$ & 34 & $14(8-25)$ & 0.001 \\
$\begin{array}{l}\text { Pengetahun } \\
\text { Sesudah }\end{array}$ & 34 & $18(16-20)$ & \\
\hline
\end{tabular}

Uji Wilcoxon

Pengetahuan sampel sebelum diberikan konseling dengan menggunakan video makanan, skornya adalah 14 dengan nilai terendah 8 dan tertinggi 25 , setelah diberikan konseling menjadi 18 dengan nilai terendah 16 dan tertinggi 20, sehingga secara uji statistik dengan menggunakan uji Wilcoxon diperoleh nilai $p=0.001$, artinya terdapat perbedaan yang bermakna pengetahuan sebelum dan sesudah pemberian konseling video makanan.

e. Perbedaan Kepatuhan Diet Sebelum Dan Sesudah Diberikan KonselingVideo Makanan

Tabel 6. Analisis Bivariat Uji Beda Paired T-Test

\begin{tabular}{lccc}
\hline & $\mathrm{n}$ & Rerata \pm SD & $p$ \\
\hline Kepatuhan Diet Sebelum & 34 & $20.6 \pm 4.73$ & 0.023 \\
Kepatuhan Diet Sesudah & 34 & $24.4 \pm 3.72$ & \\
\hline \multicolumn{2}{c}{ Terdapat perbedaan yang } & bermakna & kepatuhan diet sebelum dan sesudah
\end{tabular}
diberikan konseling dengan video makanan, dimana nilai $p=0,023(p<0.005)$.

\section{PEMBAHASAN}

Konseling gizi merupakan suatu bentuk pendekatan yang digunakan dalam asuhan gizi untuk menolong individu dan keluarga memperoleh pengertian yang lebih baik tentang dirinya serta permasalahan yang dihadapi. Setelah melakukan konseling, diharapkan individu dan keluarga mampu mengambil langkah-langkah untuk mengatasi masalah gizinya termasuk perubahan pola makan serta memecahkan masalah terkait gizi (Cornelia dkk, 2016). 
Video makanan merupakan salah satu media penyampai pesan yang dianggap efektif. Pengetahuan yang ada pada seseorang diterima melalui indera. Menurut penelitian para ahli,indera yang paling banyak menyalurkan pengetahuan ke otakadalah indera pandang. Kurang lebih $75 \%$ sampai $87 \%$ dari pengetahuan manusia diperoleh / disalurkan melalui indera pandang, 13\% melalui indera dengar dan $12 \%$ lainnya tersalurmelalui indera yang lain (Tuzzahro, 2015).

Pemberian konseling gizi dengan memanfaatkan media video makanan dapat meningkatkan tingkat pengetahuan gizi terutama pengetahuan makanan bagi pasien diabetes mellitus yaitu sebelum diberikan konseling sebanyak 22 orang $(64,7 \%)$ memiliki tingkat pengetahuan kurang dan setelah diberikan konseling gizi sebanyak 12 orang mengalami peningkatan pengetahuan dibandingkan sebelum dan setelah pemberian konseling gizi sebanyak 34 orang memiliki tingkat pengetahuan yang baik. Penelitian ini sejalan dengan penelitian yang dilakukan oleh Dyson, Beatty, dan Matthews (2010) yaitu penggunaan mediavideo dalam konseling gizi berdampak signifikan terhadappeningkatan pengetahuan pasien DM yangbaru terdiagnosa DM tipe 2.

Sattar dkk, (2003) dalam Rosadi (2017) mengatakan laki-laki memiliki risiko lebih besar terkena Diabetes Melitus Tipe 2 dibandingkan perempuan, hal ini karena pada laki-laki terjadi penumpukan lemak yang terkonsentrasi di sekitar perut sehingga memicu obesitas sentral yang lebih beresiko memicu gangguan metabolisme sehingga laki-laki lebih rentan terhadap Diabetes Melitus Tipe 2. Laki-laki biasanya bersifat lebih aktif dalam hal pengobatan dibandingkan perempuan, karena mereka memiliki tanggung jawab terhadap keluarga sehingga mereka lebih patuh.

Kepatuhan pasien terhadap manajemen DM merupakan salah satu kendala pada diabetes, para penderita diabetes banyak yang merasa tersiksa sehubungan dengan jenis dan jumlah makanan yang dibatasi (Nurhidayat, 2017). Responden yang tidak patuh terhadap anjuran disebabkan oleh beberapa faktor diantaranya, meningkatnya umur/usia responden menyebabkan terjadinya penurunanan daya ingat (lupa) sehingga responden tidak mampu mengenal atau mengingat sesuatu yang pernah dipelajari atau dialami, tingkat pendidikan yang mempengaruhi pola pikir responden terhadap pentingnya diet sesuai anjuran bagi kesehatannya (Notoadmodjo, 2005).

Hasil analisis statitika dengan menggunakan uji Paired T-test diperolah terdapat perbedaan yang bermakna antara tingkat kepatuhan diet sebelum dan sesudah diberikan konseling gizi menggunakan video makanan. Pada dasarnya tingkat kepatuhan diet sebelum diberikan konseling gizi adalah baik. Hal ini semata bukan karena tingkat pengetahuan yang dimiliki tetapi karena adanya kecenderungan untuk tidak mau mengambil resiko sehingga mereka memilih untuk patuh terhadap diet yang diberikan Ahli Gizi selama mendapatkan perawatan di Rumah Sakit. Pemberian edukasi gizi dengan menggunakan media video makanan diharapkan akan memberikan tingkat pengetahuan yang baik terhadap diet yang sedang mereka jalani sehingga menimbulkan keinginan dan sikap untuk mematuhi diet yang dijalani bukan hanya pada saat dirawat di rumah sakit tapi sampai sampel (pasien) kembali ke rumah (Dewi dan Wawan, 2010).

Faktor lain yang berperan dalam kepatuhan diet adalah durasi menderita DM. PenderitaDM yang mengalami sakit lama mengalami kejenuhan dan beresiko terjadinya komplikasi. Diabetes Melitus (DM) selain dikenal sebagai penyakit, juga dikenal sebagai faktor resiko. Penderita dengan durasi menderita penyakit DM lebih 
dari 6 bulan mengalami kecenderungan komplikasi baik akut yaitu hipoglikemi dankronis yaitu penyakit jantung, pembuluh darah,gagal ginjal gangguan penglihatan, impotensi,ulkus pada kaki, dan gangrene (Abdullah dkk, 2013).

\section{KESIMPULAN}

Pengetahuan sampel sebagian besar mengalami peningkatan setelah diberikan konseling gizi dengan menggunakan video makanan yaitu sebesar $64.7 \%$. Demikian juga tingkat kepatuhan diet pasien meningkat sebesar $97.1 \%$, dan kadar gula darah mengalami penurunan yaitu $195,2 \mathrm{md} / \mathrm{dL}$

\section{DAFTAR PUSTAKA}

Almatsier S. 2010. Penuntun Diet Edisi Baru. PT Gramedia Pustaka Utama, Jakarta.

Abdullah Bin Arif, Agus Budiyanto, dan Hoerudin, 2013 dalam Nilai Indeks Glikemik Produk Pangan dan Faktor-Faktor yang memengaruhinya (Glicemic Index of Foods and Its Affecting Factors) http://ejurnal.litbang.pertanian.go.id/index.php/jppp/article/view/1347 (diakses tgl 2 april 2018)

Cornelia, dkk. 2016. Konseling Gizi. Penebar Plus, Jakarta.

Dewi \& Wawan, 2010. Dalam BAB II Tinjauan Pustaka. http://digilib.unimus.ac.id/files/disk1/132/itptunimus-gdl-intanindah-6561-3babii.pdf (Diakses tanggal 26 Juni 2018)

Depkes, 2008. Pedoman Pengendalian Diabetes Mellitus dan Penyakit Metabolik. Jakarta.

Dyson, P.A, Beatty, S, and Matthews, 2010. An assessment of lifestyle video education for people newlye diagnosed with type 2 diabetes. Journal of Human Nutrition and Dietetics. Volume 23, Issue 4, pages 353-359, August 2010.

Mistra. 2004. 3 Jurus Melawan Diabetes Melitus. Puspa Swara, Jakarta.

Notoatmodjo. 2005. Dalam BAB II Tinjauan Pustaka. http://digilib.unimus.ac.id/files/disk1/132/itptunimus-gdl-intanindah-6561-3babii.pdf (Diakses tanggal 26 Juni 2018)

Nurhidayat I, 2017. Faktor-Faktor yang Berhubungan dengan Kepatuhan Penatalaksanaan Diet Pada Pasien Diabetes Melitus. http://repository.umy.ac.id/bitstream/handle/123456789/15591/L.\%20LAMPIRA N\%20KTI.pdf?sequence=12\&isAllowed=y (Diakses tanggal 11 Juli 2018)

Puteri Fadillah Zahra, I Dewi Marhaeni Diah Harawati, Miftahurachman. 2015 dalam Gambaran Pelayanan Konseling Gizi pada Pasien Diabetes Melitus Tipe 2 di Puskesmas Jatinangor http://jurnal.unpad.ac.id/jsk ikm/article/download/10380/4744 (Diakses tgl 5 april 2018)

Rosadi, 2017. Dalam BAB II Tijauan Pustaka. http://repository.ump.ac.id/4604/3/KHAERUL\%20ANWAR\%20ROSADI\%20BA B\%20II.pdf (Diakses tanggal 26 Juni 2018) 
GIZIDO Volume 11 No.2 November 2019 Media Video Makanan Nonce N. dkk

Soegondo S, dkk. 2013. Penatalaksanaan Diabetes Melitus Terpadu. Balai Penerbit FKUI, Jakarta.

Tuzzahroh F. 2015. Pengaruh penyuluhan gizi seimbang dengan media video, poster dan permainan kwartet gizi terhadap pengetahuan gizi dan status gizi siswa disekolah dasar negeri karangasem III kota Surakarta. http://eprints.ums.ac.id/39769/18/NASKAH\%20PUBLIKASI.pdf (Diakses tgl 26 Juni 2018) 